\title{
Calanus finmarchicus diel and seasonal rhythmicity in relation to endogenous timing under extreme polar photoperiods
}

\author{
N. Sören Häfker ${ }^{1,2, *}$, Mathias Teschke ${ }^{1}$, Lukas Hüppe ${ }^{2}$, Bettina Meyer $^{1,2,3, *}$ \\ ${ }^{1}$ Alfred Wegener Institute Helmholtz Centre for Polar and Marine Research, 27570 Bremerhaven, Germany \\ ${ }^{2}$ Institute for Chemistry and Biology of the Marine Environment, University of Oldenburg, 26111 Oldenburg, Germany \\ ${ }^{3}$ Helmholtz Institute for Functional Marine Biodiversity at the University of Oldenburg, 26129 Oldenburg, Germany
}

\begin{abstract}
Changing environmental conditions cause poleward distribution shifts in many marine organisms including the northern Atlantic key zooplankton species Calanus finmarchicus. The copepod has diel cycles of vertical migration and feeding, a seasonal life cycle with diapause in winter and a functioning circadian clock. Endogenous clock mechanisms control various aspects of rhythmic life and are heavily influenced by environmental light conditions. Here we explore how the extreme seasonal change in photoperiod (day length) in a high Arctic fjord affects circadian clock functioning as well as diel and seasonal cycles in C. finmarchicus. Expression of clock genes was measured in the active life phase at the end of midnight sun, in early diapause when photoperiod was $\sim 12 \mathrm{~h}$, and in late diapause during the polar night. While the clock maintained diel rhythmicity under extremely long photoperiods, it became arrhythmic during diapause. This was probably not due to a lack of light but was related to the physiological state of diapause. Seasonal expression analyses of 35 genes show distinct patterns for each investigated life phase. C. finmarchicus is able to maintain diel clock rhythmicity at photoperiods close to $24 \mathrm{~h}$, and it is discussed how this may be related to the nature of the marine environment. The work also evaluates the potential negative consequences of rigid clock-based seasonal timing in a polar environment exposed to climate change and with high interannual variability.
\end{abstract}

KEY WORDS: Calanus finmarchicus · Circadian clock · Midnight sun · Polar night $\cdot$ Photoperiod · Gene expression $\cdot$ Diel cycle $\cdot$ Seasonal cycle

\section{INTRODUCTION}

The copepod Calanus finmarchicus is a key zooplankton species in the northern Atlantic food web that provides a crucial trophic link between primary production and commercially important fish stocks (Runge 1988, Prokopchuk \& Sentyabov 2006). The species inhabits a large latitudinal range from $\sim 40^{\circ}$ up to $80^{\circ} \mathrm{N}$ and often dominates zooplankton biomass (Kwasniewski et al. 2003, Helaouët \& Beaugrand 2007). C. finmarchicus performs diel vertical migration (DVM), meaning that the copepods migrate to surface waters at night to feed on phytoplankton and retreat to

${ }^{*}$ Corresponding authors: soeren.haefker@awi.de, bettina.meyer@awi.de deeper water layers during the day to hide from visual predators (Dale \& Kaartvedt 2000). C. finmarchicus further shows diel cycles of feeding as well as respiration and enzyme activity (Båmstedt 1988). The copepod's seasonal life cycle is characterized by distinct physiological phases starting with spawning and active development in surface waters in spring and summer, when phytoplankton is abundant (Hirche 1996a, Baumgartner \& Tarrant 2017). During this time, the animals develop through 5 larval stages as well as 5 juvenile copepodid stages (CI-CV) and accumulate a considerable amount of energy-rich wax esters in a lipid sac (Falk-Petersen et al. 2009, Clark et al. 2013).

() The authors 2018. Open Access under Creative Commons by Attribution Licence. Use, distribution and reproduction are unrestricted. Authors and original publication must be credited. 
The lipid-rich CV stages migrate into deeper water layers where they enter diapause, a phase of overall reduced activity and fasting that lasts until spring (Hirche 1996a, Ingvarsdóttir et al. 1999). While C. finmarchicus CV copepodids at lower latitudes may molt directly into adults and produce up to 3 generations per year before entering diapause (Melle et al. 2014), at higher latitudes the species spawns only 1 generation per year that then enters diapause in the CV stage (Kwasniewski et al. 2003, Melle et al. 2014). The emergence from diapause starts in winter at depth, indicated by increasing metabolic activity and the development of reproductive tissues (Hirche 1996b, Ingvarsdóttir et al. 1999). Ultimately, the copepods molt to adults and ascend to surface waters to spawn a new generation that can then benefit from the spring phytoplankton bloom (Hirche 1996a, Baumgartner \& Tarrant 2017). Although both the seasonal cycle of $C$. finmarchicus and its diel cycle of activity and migration have been described in great detail, the mechanisms controlling diel and seasonal rhythmicity are still poorly understood (Baumgartner \& Tarrant 2017, Häfker et al. 2017).

A potent molecular tool for the regulation of diel and seasonal cycles is the circadian clock, which generates an endogenous rhythm of $\sim 24 \mathrm{~h}$ length (Latin: circa dies, meaning about a day), thus enabling organisms to anticipate the rhythmic changes of the day-night cycle. The molecular machinery of circadian clocks is based on so-called clock genes and their protein products that interact with each other in feedback loops, with the genes ultimately inhibiting their own transcription (Mackey 2007). The expression patterns of most clock genes show diel rhythms, with peak levels often being associated with sunset or sunrise (MeirelesFilho \& Kyriacou 2013). Several clock-associated genes regulate and delay the accumulation of the clock proteins as well as their import into the nucleus, resulting in a cycle period of $\sim 24 \mathrm{~h}$ (Mackey 2007). Although this cycle persists under constant darkness, the clock is not perfectly precise and needs to be entrained (synchronized) by external cues on a regular basis to stay in tune with the environment. Light is by far the most common cue used for this entrainment (Aschoff 1954). Circadian clocks affect organisms on various organizational levels, reaching from diel rhythms of gene expression and enzyme activity to the control of the sleep-wake cycle and the regulation of DVM in fish and zooplankton including C. finmarchicus (Dunlap \& Loros 2016, Häfker et al. 2017).

Another crucial feature of the circadian clock is the ability to measure photoperiod (day length) and thus to provide information about the seasonal cycle (Goto
2013). Various arthropods, including several copepod species, use changes in photoperiod as a cue for the timing of seasonal life cycle events like reproduction or diapause (Marcus \& Scheef 2010, Goto 2013). For C. finmarchicus, the involvement of clock-based photoperiod measurement in seasonal timing and diapause has been proposed but is controversial (Miller et al. 1991, Baumgartner \& Tarrant 2017).

Circadian clocks have been explored in great detail in terrestrial model species such as Drosophila and mice, but investigations of marine clock systems are still scarce (Tessmar-Raible et al. 2011). This is particularly true for high-latitude systems with the most poleward study on marine clocks conducted at $65^{\circ} \mathrm{S}$ (Teschke et al. 2011). However, the polar regions pose a special challenge to circadian clocks due to the extreme seasonal changes in photoperiod, reaching from permanent light in summer (midnight sun) to permanent darkness in winter (polar night). There are several studies reporting diel rhythms in marine organisms during midnight sun or the polar night (e.g. Dale \& Kaartvedt 2000, Last et al. 2016), but the mechanistic basis of these rhythms remains completely unknown. Also, the productive period at high latitudes is short, meaning that precise timing of seasonal life cycle events like the emergence from diapause can be crucial for survival and population size (Søreide et al. 2010). In the face of changing environmental conditions, C. finmarchicus and many other marine species have experienced a poleward distribution shift (Reygondeau \& Beaugrand 2011, Chivers et al. 2017). As a consequence, the circadian clock of the originally boreal C. finmarchicus is exposed to the more extreme polar light conditions that were shown to affect circadian clock functioning and rhythmicity in various species (Cottier et al. 2006, Beale et al. 2016). This could affect copepod fitness, population size and distribution (Søreide et al. 2010, Saikkonen et al. 2012). Here we investigate how the strong seasonal changes in photoperiod in an Arctic fjord affect the diel rhythmicity as well as the seasonal life cycle of $C$. finmarchicus with respect to gene expression, physiology and behavior and discuss how endogenous clock systems may increase or reduce fitness under the extreme polar light conditions.

\section{MATERIALS AND METHODS}

\section{Study site characteristics}

Kongsfjorden is an Arctic fjord situated in the western part of the Svalbard archipelago (Fig. 1). Because 


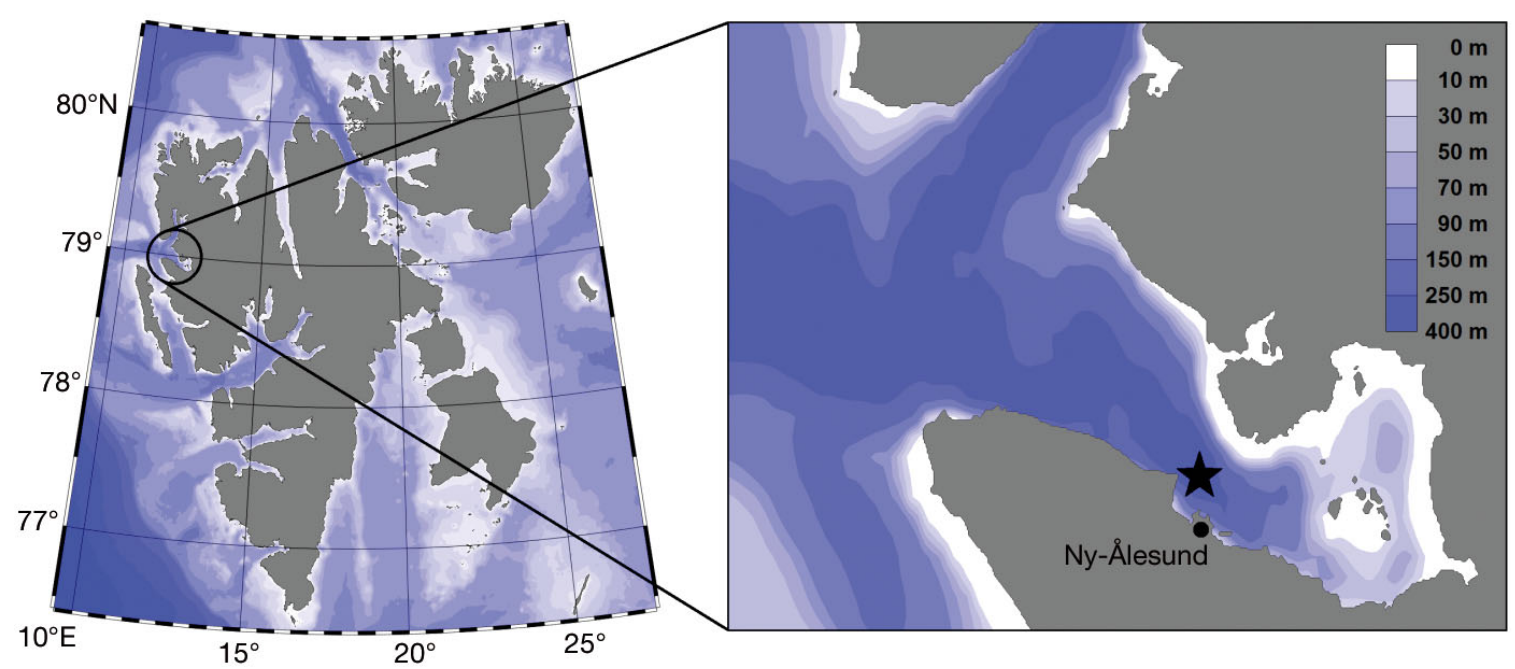

Fig. 1. Kongsfjorden and the Svalbard archipelago. Samples were collected at sampling site KB3 (star). Copepods in early and late diapause (September 2014 and January 2015, respectively) were collected and sorted onboard the R/V 'Helmer Hanssen', while active copepods (August 2016) were collected onboard the R/V 'Teisten' and sorted at the Kings Bay Marine Laboratory in Ny-Ålesund

of its depth of $>300 \mathrm{~m}$ and the lack of a sill at the fjord entrance, it can be influenced by the influx of Arctic and Atlantic water masses (Cottier et al. 2005). Data on diel changes in surface photosynthetically active radiation (PAR, measured at 385-695 nm in Ny-Ålesund) were obtained from the database of the Baseline Surface Radiation Network. PAR attenuation with depth was calculated based on the mean surface PAR from 10:00 to $14: 00 \mathrm{~h}$ for a $1 \mathrm{wk}$ period ending with the day of the respective sampling and considering a $10 \%$ loss at the air-water interface (J. Cohen pers. comm.). The effect of phytoplankton on attenuation with depth was considered by calculating the attenuation coefficient $\left(K_{P A R}\right)$, based on the mean phytoplankton concentration in the water column (data provided by Malin Daase, The Arctic University of Norway [UiT], Tromsø) according to the reports of Schanz (1985) and Lutz et al. (1996).

Table 1. Life phase samplings in Kongsfjorden. Samplings were performed in September 2014 (early diapause), January 2015 (late diapause) and August 2016 (active phase). Samples for gene expression were collected according to the diel time series. Samplings for dry weight, carbon to nitrogen (C:N) ratio and lipid analyses were performed at midday for each life phase

\begin{tabular}{|c|c|c|}
\hline Life phase & Diel time series (no. of diel time points) & Depth \\
\hline Active phase & $\begin{array}{l}\text { Aug } 25 \text { 00:00-Aug } 25 \text { 08:00 + } \\
\text { Aug } 27 \text { 12:00-Aug } 28 \text { 00:00 }(3+4)\end{array}$ & Surface-150 m \\
\hline Early diapause & Sep 26 00:00-Sep 27 00:00 (7) & 200 m-bottom ${ }^{a}$ \\
\hline Late diapause & Jan 13 04:00-Jan 14 00:00 (6) & 200 m-bottom \\
\hline
\end{tabular}

Decrease of PAR with depth was then calculated in $1 \mathrm{~m}$ intervals based on the Beer-Lambert equation $\mathrm{PAR}_{x}=\mathrm{PAR}_{0} \times \mathrm{e}^{-K_{P A R} \times x}$ with $\mathrm{PAR}_{0}$ representing the mean surface PAR for the respective season $-10 \%$ and $x$ representing the depth in meters.

\section{Copepod sampling}

Calanus finmarchicus CV stages were collected at Kongsfjorden permanent sampling station KB3 $\left(78^{\circ} 57^{\prime} \mathrm{N}, 11^{\circ} 57^{\prime} \mathrm{E}\right)$ onboard the R/V 'Helmer Hanssen' (UiT) in September 2014 and January 2015 and onboard the R/V 'Teisten' (Kings Bay AS, NyÅlesund) in August 2016 (Table 1). In September 2014 and August 2016, a WP3 net $(\varnothing=1 \mathrm{~m}$, mesh size $=1000 \mu \mathrm{m}$ ) was used, whereas in January 2015, a WP2 net $(\varnothing=0.5 \mathrm{~m}$, mesh size $=200 \mu \mathrm{m})$ was used. Different net types were not expected to have an effect, as both types should sample the relatively large C. finmarchicus CV stage efficiently (Kwasniewski et al. 2003). In September 2014 and January 2015 (early and late diapause, respectively), the net was opened $\sim 10 \mathrm{~m}$ above the bottom, towed vertically and closed at $200 \mathrm{~m}$ depth. Bottom depth at the sampling site varied because of boat drift but was mostly between 340 and $355 \mathrm{~m}$, with 2 exceptions ( 285 and $315 \mathrm{~m}$ ). In August 2016 (active phase), the net 
was lowered to $150 \mathrm{~m}$, opened and then towed to the surface. For each life phase, a diel time series was created by collecting samples at $4 \mathrm{~h}$ intervals over a period of 20 to $24 \mathrm{~h}$ from midnight to midnight. Sampling intervals of $4 \mathrm{~h}$ have been used successfully to display diel clock gene cycling before, and as clock genes showed strongest expression changes at sunrise and sunset, starting and ending the sampling at midnight ensures a proper coverage of these times of strongest change (Häfker et al. 2017). While in January 2015 net failure resulted in the loss of the first diel time point, weather conditions in August 2016 forced an interruption of the sampling, resulting in a gap in the diel time series (Table 1).

After net retrieval, copepods for gene expression analysis were fixed as bulk samples immediately in RNAlater $^{\circledR}$ (Ambion) and later sorted for C. finmarchicus CV stages in RNAlater at $4^{\circ} \mathrm{C}$ using a dissection microscope. Copepods for analyses of lipid content and carbon to nitrogen (C:N) ratio were collected once at midday for each life phase and were sorted alive using dissecting microscopes either onboard (September and January) or at the Kings Bay Marine Laboratory, Ny-Ålesund (August), and were fixed in liquid nitrogen. The exposure to light was minimized (red light used for sorting), and copepods were kept at in situ temperature before and during sorting. To avoid contamination of samples with the congener species C. glacialis, samples were sorted based on prosome length classes by Kwasniewski et al. (2003). Genetic analyses showed, however, that prosome length alone is not a sufficiently reliable identification feature, and thus individuals with reddish antennae were also excluded, as this is a strong indicator for C. glacialis (Gabrielsen et al. 2012, Nielsen et al. 2014). Sorting of copepods for lipid and C:N ratio analyses took a maximum of $1 \mathrm{~h}$.

\section{Gene expression analysis}

A total of 35 genes were investigated based on their involvement in different metabolic processes including the circadian clock machinery, energy and lipid metabolism, digestion, stress response and light perception. A detailed gene list is given in Table S1 in the Supplement at www.int-res.com/articles/suppl/m603 p079_supp.pdf. Gene sequences were identified from a C. finmarchicus transcriptome (Christie et al. 2013, Lenz et al. 2014) using annotated sequences from other crustaceans. All obtained gene sequences were verified and checked for palindromic sequences and repeats as described by Häfker et al. (2017). Gene se- quences were used to design custom TaqMan ${ }^{\circledR}$ lowdensity array cards (Applied Biosystems, https://www. thermofisher.com/order/custom-genomic-products/ tools/gene-expression/), and designed primer and probe sequences were checked via BLASTN against NCBI for gene specificity. NCBI accession numbers of genes identified from the transcriptome as well as TaqMan primer and probe sequences can be accessed via PANGAEA (https://doi.pangaea.de/10.1594/ PANGAEA.884073).

RNA of C. finmarchicus CV stages was extracted using the RNeasy ${ }^{\circledR}$ Mini Kit (Quiagen) with $0.14 \mathrm{M}$ $\beta$-mercaptoethanol added to the extraction buffer. For each sample, 15 copepods were pooled. Genomic DNA residues were removed with the TURBO DNA-free Kit (Life Technologies). Extracted RNA was checked for degradation (2100 Bioanalyzer/RNA 6000 Nano Kit, Agilent Technologies) and investigated for contaminants and RNA concentration (NanoDrop 2000 Spectrophotometer, Thermo Fisher Scientific). Next, $2 \mu \mathrm{g}$ RNA per sample were converted to cDNA using RevertAid H Minus Reverse Transcriptase (Invitrogen). Finally, samples were distributed to Taq$\mathrm{Man}^{\circledast}$ cards, and gene expression was measured via real-time quantitative PCR (ViiA ${ }^{\mathrm{TM}} 7$, Applied Biosystems).

Gene expression was normalized according to Livak \& Schmittgen (2001) using the $2^{-\Delta \Delta C T}$ method. For investigations of diel expression patterns, each of the diel time series from each of the 3 life phases (active phase, early diapause, late diapause) was normalized individually against the geometric mean of the housekeeping genes elongation factor $1 \alpha, R N A$ polymerase II and actin (6-7 diel time points per life phase, $\mathrm{n}=5$ replicates per diel time point and gene). For life phase comparisons, each of the 3 diel times series was pooled, resulting in gene expression data for 3 life phases (active, early diapause, late diapause) that were normalized against the geometric mean of elongation factor $1 \alpha$ and RNA polymerase II ( 3 life phases, $\mathrm{n}=30-35$ replicates per life phase and gene). Housekeeping genes were chosen based on expression stability and the results of previous studies (Hansen et al. 2008, Tarrant et al. 2008, Clark et al. 2013, Fu et al. 2013, Häfker et al. 2017).

\section{Dry weight, C:N ratio and lipid content}

For the determination of dry weight and C:N ratio, $\mathrm{n}=24$ individual copepods per life phase were freeze dried in pre-weighed tin caps. The dry weight was then measured gravimetrically. This was followed by 
measurement of the $\mathrm{C}: \mathrm{N}$ ratio via elemental analyzer (EuroEA, EuroVector).

Lipid samples were measured according to Folch et al. (1957). For each sample, $20 \mathrm{CV}$ stages were pooled with $\mathrm{n}=5$ replicates per life phase. Frozen copepods were homogenized in $4 \mathrm{ml}$ chloroform: methanol (2:1 v/v) (T10 ULTRA-TURRAX ${ }^{\circledR}$ disperser, IKA). The homogenate was then filtered through a pre-washed Whatman ${ }^{\circledR}$ No. 1 filter (GE Healthcare). Next, $1 \mathrm{ml}$ potassium chloride $(0.88 \% \mathrm{w} / \mathrm{v})$ was added, and the homogenate was thoroughly vortexed and centrifuged at $400 \times g$ for $2 \mathrm{~min}$ to induce phase separation. The upper aqueous phase was discarded, and the remaining lower phase was dried under a stream of nitrogen gas. Finally, samples were freeze dried for $6 \mathrm{~h}$, and total lipid content ( $\mu \mathrm{g}$ ind. ${ }^{-1}$ ) was determined gravimetrically (XP6U Micro Comparator, Mettler-Toledo).

\section{Statistics}

Statistical analyses were done in RStudio (v. 0.99.442, R Development Core Team 2013). Diel time series of clock gene expression were checked for $24 \mathrm{~h}$ cycling using the R package RAIN (Thaben \& Westermark 2014). A significance level of $\alpha=0.001$ was used to account for the number of investigated genes (8 clock genes tested). Life phase differences in gene expression, dry weight, lipid content and C:N ratio were identified via Kruskal-Wallis ANOVAs on ranks followed by Dunn's multiple comparison post hoc tests provided in the FSA R package. For gene expression analyses, $\alpha=0.0001$ was used (35 genes

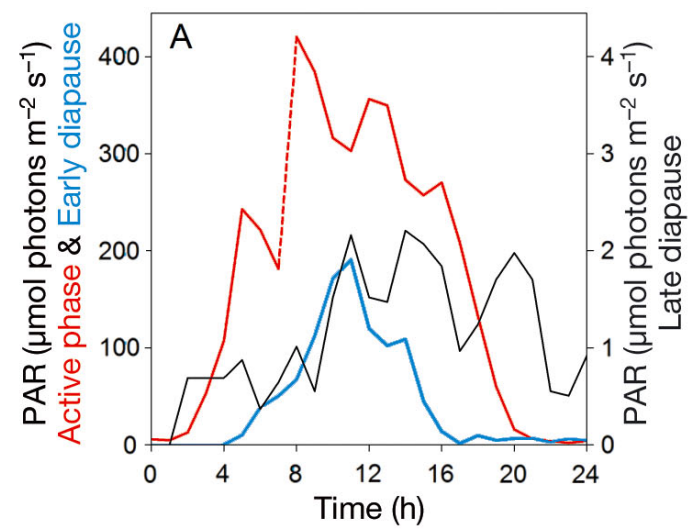

tested), whereas for dry weight, lipid content and C:N ratio, the significance level was $\alpha=0.05$. Graphs were created via SigmaPlot (v. 12.5).

\section{RESULTS}

\section{Light conditions in Kongsfjorden}

During the active phase in August, photoperiod (from sunrise to sunset) was close to $24 \mathrm{~h}$, but there was still a clear diel rhythm of surface PAR intensity with a noon maximum of $\sim 400 \mu \mathrm{mol}$ photons $\mathrm{m}^{-2} \mathrm{~s}^{-1}$ (Fig. 2A). In September (early diapause), photoperiod was $\sim 12 \mathrm{~h}$ and PAR intensity peaked at $\sim 190 \mu \mathrm{mol}$ photons $\mathrm{m}^{-2} \mathrm{~s}^{-1}$. During late diapause in January, there was no clear diel rhythm in PAR intensity and maximum values reached $\sim 1.5 \mu \mathrm{mol}$ photons $\mathrm{m}^{-2} \mathrm{~s}^{-1}$. It is, however, possible that the reflection of artificial light by clouds led to an overestimation of irradiance in January. PAR attenuation with depth was similar in August and September, with the detection limit reported for Calanus $\left(5 \times 10^{-8} \mu \mathrm{mol}\right.$ photons $\mathrm{m}^{-2} \mathrm{~s}^{-1}$, Båtnes et al. 2015) reached at $\sim 120 \mathrm{~m}$ depth (Fig. 2B). During the polar night in January, surface PAR was much weaker and the detection limit was reached at $\sim 80 \mathrm{~m}$ depth or, if artificial light caused an overestimation, at even shallower depth.

\section{Diel clock gene expression}

The $24 \mathrm{~h}$ cycling of clock gene expression was mostly confined to the active life phase in surface

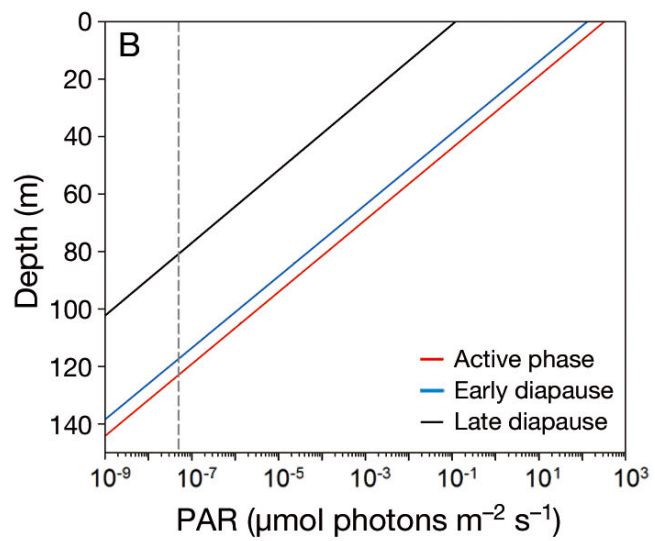

Fig. 2. Light conditions in Kongsfjorden. (A) Diel change in surface photosynthetically active radiation (PAR) during the samplings. The sampling during the active phase had to be interrupted due to bad weather conditions (see also Table 1); hence, light data from August 25 and 27 are shown (gap indicated by dashed line). (B) PAR attenuation with depth. Attenuation was calculated considering phytoplankton concentration (data provided by Malin Daase, The Arctic University of Norway

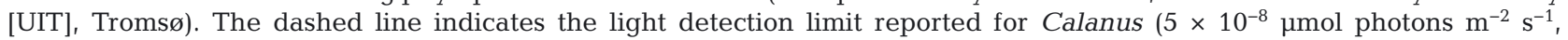
Båtnes et al. 2015) 
waters in August (Fig. 3). During the active phase when photoperiod was close to $24 \mathrm{~h}$, the clock genes period1 (per1), timeless (tim), cryptochrome2 (cry2) and clockwork orange (Cwo) showed significant $24 \mathrm{~h}$ cycling. During early diapause in September, the photoperiod was close to $12 \mathrm{~h}$ and diel expression cycling at depth below $200 \mathrm{~m}$ was confined to the genes clock (clk) and period2 (per2). In late diapause during the polar night (January), $24 \mathrm{~h}$ rhythmicity was completely absent. The clock genes cycle $($ сус $)$ and vrille (vri) did not show significant cycling in any of the life phases.

In the active phase, cycling clock genes showed maximum expression in the afternoon, with peak times reaching from close to noon ( $c w o$ ) to around $16: 00 \mathrm{~h}$ (per1, tim) to sunset (cry2) (Fig. 3). In early diapause, clk and per2 showed minimum expression before sunrise, but while clk reached maximum expression around noon, expression of per2 gradually increased and peaked at 20:00 h, i.e. after sunset.

\section{Life phase differences in gene expression}

Most of the investigated genes showed clear expression differences between life phases (Table S1 in the Supplement). The majority of genes peaked in expression during the active phase, including most of the clock genes (e.g. clk, per2, cwo ) and several clock-associated genes (e.g. cry1, doubletime2 [dbt2]) (Fig. 4). Other genes elevated during the active phase were involved in food digestion and metabolization (chymotrypsin [chtrp], phosphofructokinase

Fig. 3. Diel clock gene expression. Diel expression changes of the clock genes (A) clock (clk), (B) cycle $(\mathrm{cyc}),(\mathrm{C})$ period1 (per1), (D) period2 (per2), (E) timeless (tim), (F) crytochrome2 (cry2), (G) clockwork orange $(\mathrm{cwo})$ and $(\mathrm{H})$ vrille (vri) are shown. Color bars indicate day (yellow) and night (black). The sampling during the active phase had to be interrupted because of bad weather conditions (see also Table 1); hence, data from August 25 and 27 are shown (gap indicated by dashed lines). Genes were investigated for $24 \mathrm{~h}$ rhythmicity via RAIN analysis, and p-values are shown. Significant $24 \mathrm{~h}$ cycling $(p<0.001)$ is indicated in bold. Mean values \pm SEM are shown
Active phase
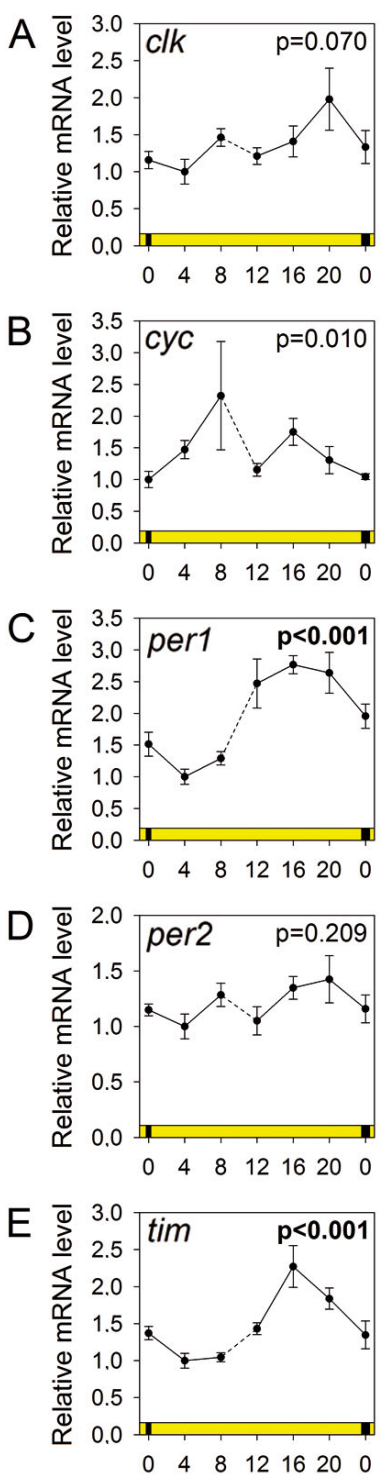

F
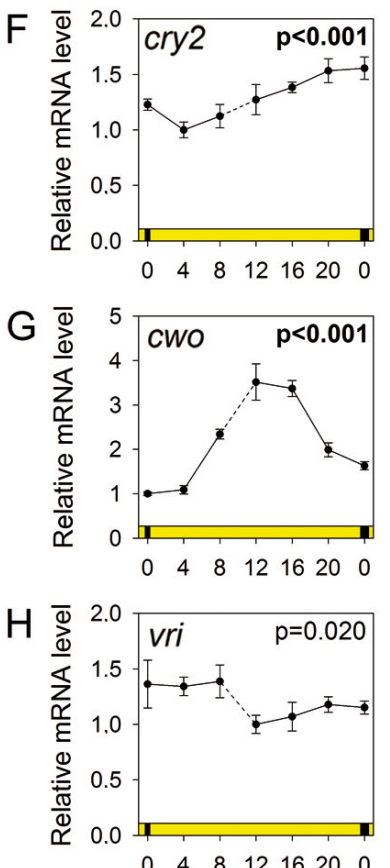

Early diapause
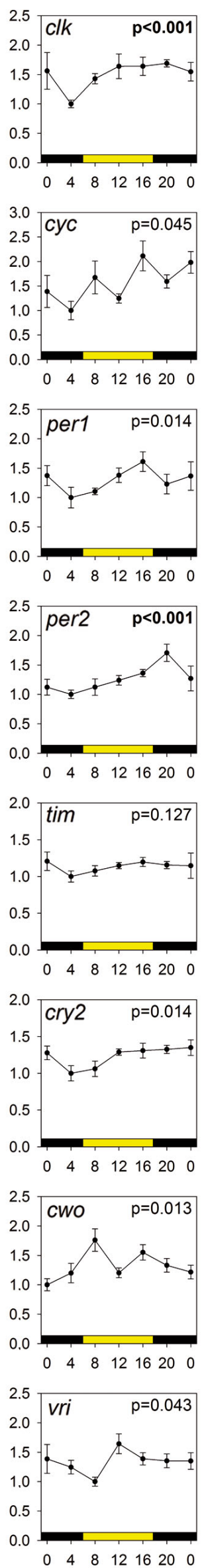

Time (h)
Late diapause
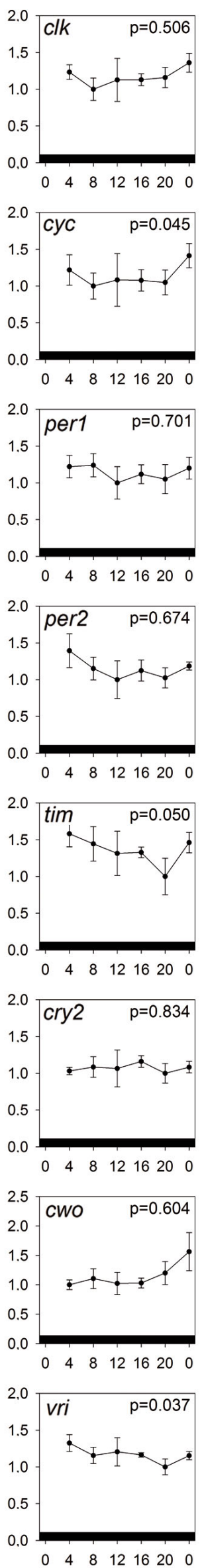


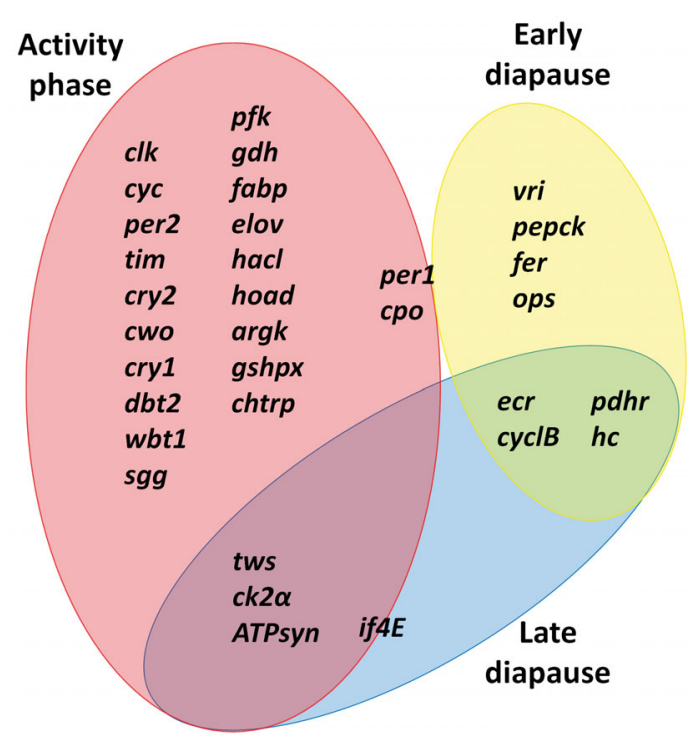

Fig. 4. Life phase-dependent changes in gene expression. Life phases of Calanus finmarchicus CV copepodid stages were compared via Kruskal-Wallis ANOVA on ranks and Dunn's post hoc test. Circles indicate the life phases during which the respective genes showed elevated expression. For a detailed characterization of individual gene patterns (including abbreviation names), see text and Table S1 in the Supplement

[pfk], glutamate dehydrogenase [gdh], 2-hydroxyacyl-CoA lyase [hacl]) and lipid accumulation (fatty acid-binding protein [fabp], elongation of very long fatty acids protein [elov]).

In early diapause, peak expression was shown by the genes vri (clock gene), phosphoenolpyruvate carboxykinase (pepck, gluconeogenesis) and ferritin (fer, antioxidative defense), and by an opsin gene (ops, light perception) (Fig. 4). None of the investigated genes was exclusively highly expressed in late diapause. However, the clock-associated genes twins $(t w s)$ and casein kinase II $\alpha(c k 2 \alpha)$ as well as the eukaryotic translation initiation factor $4 E$ (if $4 E$, translation) and the ATP synthase $\gamma$ subunit (ATPsyn, mitochondrial energy production) showed high expression during both late diapause and the active phase. In contrast, the genes ecdysteroid receptor (ecr, molting), cyclin $B$ ( cyclB$B$, cell cycle), pigment-dispersing hormone receptor ( $p d h r$, light perception) and hemocyanin ( $h c$, blood oxygen transport) were upregulated in early and late diapause (Fig. 4).

\section{Dry weight, C:N ratio and lipid content}

Dry weight, C:N ratio and total lipid content of CV stages differed significantly between life phases $(p<$
0.05, $\mathrm{df}=2$, for each parameter). Dry weight was highest during early diapause (mean \pm SEM: $504 \pm$ $6 \mu \mathrm{g}, \mathrm{n}=24)$ compared to the active phase $(183 \pm$ $3 \mu \mathrm{g}, \mathrm{n}=22)$ and late diapause $(155 \pm 5 \mu \mathrm{g}, \mathrm{n}=22)$ when dry weights were similarly low (Fig. 5A). The $\mathrm{C}: \mathrm{N}$ ratio was lowest in the active phase $(4.73 \pm 0.05$, $\mathrm{n}=22$ ) and showed a maximum during early diapause $(8.94 \pm 0.05, \mathrm{n}=24)$ before decreasing to intermediate levels in late diapause $(6.86 \pm 0.05, \mathrm{n}=22)$ (Fig. 5B). Lowest lipid levels were measured in active
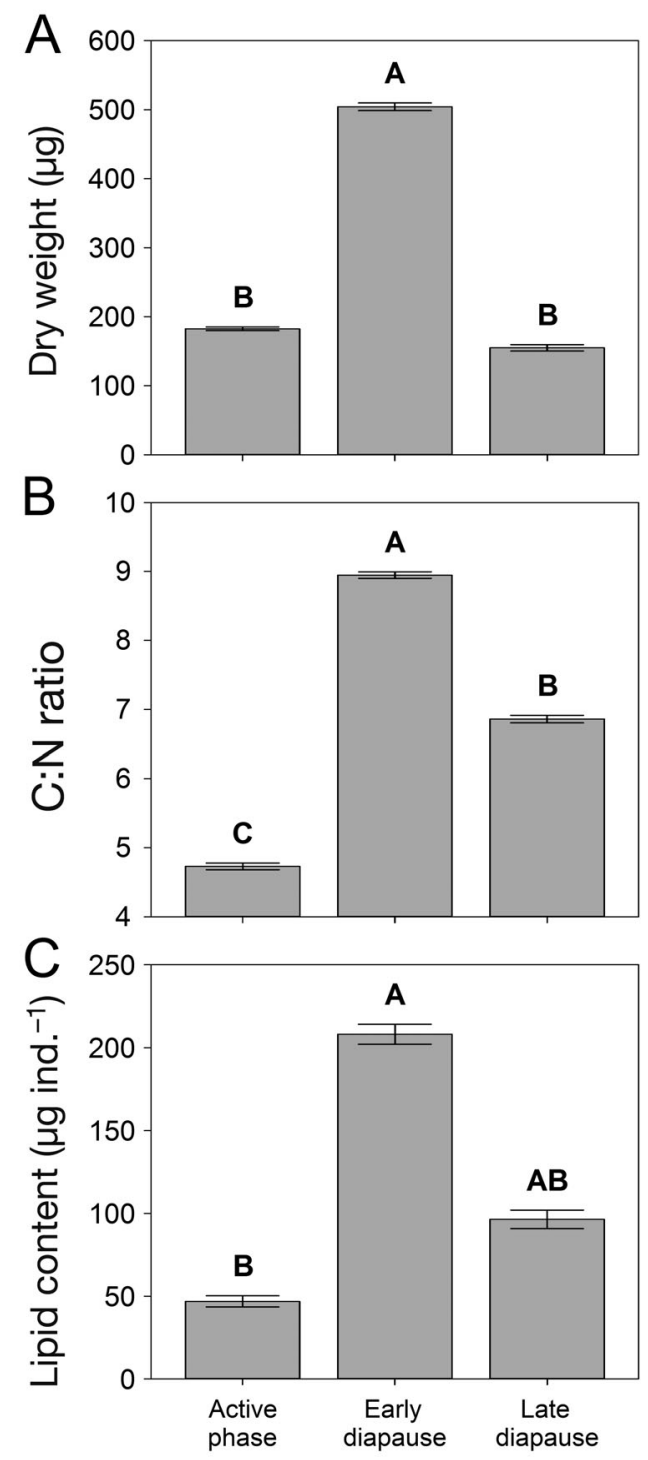

Fig. 5. Life phase-dependent changes in physiology. (A) Dry weight, (B) carbon to nitrogen (C:N) ratio and (C) lipid content of Calanus finmarchicus copepod V stages, analyzed via Kruskal-Wallis ANOVA on ranks and Dunn's post hoc test. p-values of Kruskal-Wallis ANOVAs are shown, and significant differences between life phases are indicated by different letters. Lipid content in late diapause was not significantly different from the other life phases. Mean values \pm SEM are shown 
CV copepodids ( $47 \pm 3 \mu \mathrm{g}$ ind. ${ }^{-1}, \mathrm{n}=5$ ). Lipid content was highest during early diapause $\left(208 \pm 6 \mu \mathrm{g} \mathrm{ind}^{-1}\right.$, $\mathrm{n}=5$ ) and at intermediate levels in late diapause (96 \pm 6 g ind $^{-1}, \mathrm{n}=5$ ) (Fig. 5C).

\section{DISCUSSION}

\section{Diel rhythmicity}

Our study provides new insights into the diel and seasonal rhythmicity of the boreal zooplankton key species Calanus finmarchicus in a polar environment and under extreme light conditions. During the active life phase in August, when copepods were developing and feeding in surface waters, the diel cycling in clock gene expression was strongest. The clock genes per1, tim and cwo showed the most pronounced diel expression cycles with peak activity in the afternoon, closely resembling laboratory and field patterns of an active $C$. finmarchicus population in Loch Etive, UK $\left(56^{\circ} \mathrm{N}\right.$, photoperiod $=16 \mathrm{~h}$ ) (Häfker et al. 2017). The observation that peak times coincided despite strongly differing photoperiods and latitudes suggests that $C$. finmarchicus' circadian clock can maintain a robust rhythm under long polar photoperiods. Classical terrestrial chronobiology shows that while clock rhythmicity usually persists under constant darkness, the constant presence of light does often disrupt circadian rhythms (e.g. Kobelkova et al. 2015). Accordingly, there are several reports of a lack of diel rhythmicity including DVM during midnight sun (e.g. Cottier et al. 2006). However, surface PAR nevertheless showed a clear diel cycle of light intensity (Fig. 2A) that was also present during the midnight sun period (Cottier et al. 2006). Furthermore, light intensity attenuates with water depth, and activephase copepods were collected down to $150 \mathrm{~m}$ depth. This means that the subjective photoperiod perceived by the copepods in Kongsfjorden was possibly shorter than the actual time between sunrise and sunset (Miller et al. 1991). This would explain why per1, tim and cwo, which typically peak close to sunset (Meireles-Filho \& Kyriacou 2013, Häfker et al. 2017), showed highest expression in the afternoon (Fig. 3C,E,G). The shorter subjective photoperiod at depth could support clock rhythmicity during midnight sun, enabling $C$. finmarchicus as well as other polar marine species to maintain a $24 \mathrm{~h}$ cycle even under extremely long photoperiods. It can be further speculated that the presence of sea ice would shorten the subjective photoperiod in the marine environment even more.
Samples of active copepods were collected in August, at the end of the midnight sun period, and the question remains whether $C$. finmarchicus maintains clock rhythmicity over the entire summer period of permanent (although oscillating) light. The study was conducted at a time where DVM becomes rhythmic while it is arrhythmic beforehand, and the same could apply to the clock (Cottier et al. 2006). In this context, Cottier et al. (2006) argued that rhythmic vertical migration during midnight sun may persist on the individual level but is desynchronized within the population, resulting in arrhythmic overall migration patterns, and possibly driven by hunger and/or predator avoidance. However, net catch data of C. finmarchicus show rhythmic DVM during midnight sun (Dale \& Kaartvedt 2000). For our analysis, we pooled $15 \mathrm{CV}$ copepodids per replicate and still found clear diel clock gene cycling. While this showed that $C$. finmarchicus can maintain clock rhythmicity under extremely long photoperiods, the possibility that individuals were desynchronized on a behavioral level cannot be excluded. If decoupling of migration behavior from the rhythmic clock is present, this could be an adaption to the permanent risk of visual predation during midnight sun (Cottier et al. 2006). Maintaining clock rhythmicity would, however, still be important for the temporal orchestration of different physiological processes that can interfere with each other (Panda et al. 2002). While further studies are needed for definite answers, it seems possible that $C$. finmarchicus' circadian clock can maintain rhythmicity throughout the midnight sun period.

Cycling clock gene expression during early diapause in September (photoperiod $=\sim 12 \mathrm{~h}$ ) was limited to the clock genes clk and per2, and in late diapause during the polar night, $24 \mathrm{~h}$ rhythmicity was completely absent (Fig. 3). Diapause samples were collected below $200 \mathrm{~m}$, while based on our calculations, the copepod's light detection limit $(5 \times$ $10^{-8} \mu \mathrm{mol}$ photons $\mathrm{m}^{-2} \mathrm{~s}^{-1}$, Båtnes et al. 2015) was reached at $\sim 120$ and $\sim 80 \mathrm{~m}$ depth during early and late diapause, respectively (Fig. 2B). In spite of a lack of light at depth, cycling of clock genes was reduced but still present during early diapause (Fig. 3), indicating that the clock was running endogenously. Data on C. finmarchicus clock gene cycling in a Scottish sea loch at $\sim 56^{\circ} \mathrm{N}$ show that the clock not only was arrhythmic in copepods diapausing at depth in autumn and winter but also stayed arrhythmic in diapausing animals advected to surface waters where they experienced a clear day-night cycle (Häfker et al. 2018). This strongly indicates that the reduction in clock gene cycling in early diapause in Kongsfjorden 
as well as the complete lack of clock rhythmicity in late diapause was related to the physiological transition to diapause rather than the lack of a diel light cue for clock entrainment. It is therefore likely that the extreme light conditions during the polar night will have little effect on $C$. finmarchicus.

\section{Seasonal cycle}

C. finmarchicus showed strong differences in gene expression between life phases. The majority of genes were upregulated during the active life phase in August (Fig. 4). High expressions of ATPsyn, a key component of the mitochondrial respiration chain, as well as if $4 E$, which is involved in protein synthesis, indicate high metabolic activity matching expression patterns from lower latitudes (Häfker et al. 2018) and the high respiration rates reported for this life phase (Ingvarsdóttir et al. 1999). Also, the upregulation of several genes involved in the digestion and metabolization of food ( $p f k, g d h, h a c l, c h t r p)$ and the accumulation of lipid storages (fabp, elov) during the active phase is in tune with our findings from lower latitudes in Loch Etive (Häfker et al. 2018), reflecting that this is the time when the copepods are feeding at the surface and are building up large lipid storages for the time of diapause (Falk-Petersen et al. 2009, Clark et al. 2013). This was also visible in the strong difference in dry weight, $\mathrm{C}: \mathrm{N}$ ratio and lipid content of active copepods that were still feeding in surface waters compared to animals in early diapause that had just descended to deep waters (Fig. 5). The upregulation of glutathione peroxidase (gshpx) and arginine kinase (argk) suggest an increased protection from oxidative stress $(g \operatorname{shp} x)$ and an increased capacity for anaerobic energy production (argk). This is surprising, as in C. finmarchicus, protection from oxidative stress is typically associated with diapause (Tarrant et al. 2008, Häfker et al. 2018), and anaerobic metabolism would rather be expected in deeper water layers that tend to be more hypoxic. A possible explanation may be related to the short polar productive period of phytoplankton. A limited time window for growth and lipid accumulation means that the copepods have to feed and grow as much and as fast as possible, resulting in a high energy turnover that could support oxidative stress and increase the need for additional anaerobic energy sources. Additionally, the high light levels at the end of midnight sun increase predation risk (Fortier et al. 2001), and escape responses depend on short but intense bursts of energy most likely fueled by anaerobic energy storages. Other genes that are typically associated with diapause but showed upregulation during the active phase were couch potato (сpo) and 3-hydroxyacyl-Coa dehydrogenase (hoad). While cpo is involved in the regulation of diapause in insects (Salminen et al. 2015), hoad is a key enzyme for the mobilization of lipid storages and was found to be upregulated during Calanus diapause (Freese et al. 2017, Häfker et al. 2018). Nevertheless, the decrease of dry weight, lipid content and C:N ratio from early to late diapause shows that a significant fraction of storage wax esters was metabolized during diapause (Fig. 5). The low expression of hoad in diapause thus may reflect that energy demands during this phase are reduced and that lipid storages are depleted rather slowly. The definitive reasons for the expression patterns of cpo and hoad remain unknown, and more detailed latitudinal comparisons of C. finmarchicus populations will be needed to evaluate whether the observed patterns are specifically related to the polar environment.

Most clock genes and clock-associated genes showed highest expression during the active phase, matching the time of strongest clock rhythmicity (Figs. $3 \& 4$ ), and it seems reasonable that clock genes show highest expression at the time when the clock is actually ticking. However, at lower latitudes, several clock genes of $C$. finmarchicus showed highest seasonal expression during diapause when the clock was arrhythmic (Häfker et al. 2018). To understand these latitudinal differences, a detailed understanding of the molecular interactions within the C. finmarchicus circadian clock machinery will be needed.

Genes upregulated in early diapause in September represent a variety of metabolic processes (Fig. 4). fer is part of the copepod's antioxidative defense machinery, and its high expression in diapause matches previous reports (Tarrant et al. 2008, Häfker et al. 2018). Upregulation of pepck, a key enzyme of gluconeogenesis, could reflect the mobilization of wax ester lipids from the lipid sac and their conversion to glucose for the consecutive distribution within the body (Falk-Petersen et al. 2009, Poelchau et al. 2013). $p d h r$ and a gene encoding an opsin (ops) were also upregulated in early diapause, and both genes are involved in light perception. $p d h r$ is a receptor for pigment-dispersing hormone, which reduces the eye's sensitivity to light (Strauss \& Dircksen 2010). Light can cause arousal in Calanus (Miller et al. 1991), and the upregulation of $p d h r$ may ease the transition to diapause. The nature of the opsin is unknown, meaning that its increased expression does not necessarily 
reflect increased light sensitivity but could also indicate a change in responsiveness to specific wavelengths related to the change in light composition during the descent to diapause depth. Although the exact reasons remain elusive, the upregulation of pepck, pdhr and ops in diapause was also observed in Loch Etive, supporting the correctness of our data (Häfker et al. 2018).

Notably, the clock gene vri, which did not show any diel cycling during any life phase both in this study (Fig. 3) or in previous studies (Häfker et al. $2017,2018)$, peaked in expression during early diapause. In Drosophila's circadian clock, vri is part of a separate negative feedback loop (Mackey 2007), but its mechanistic role within the clock of $C$. finmarchicus is unknown. As peak vri expression in Loch Etive also occurred in early diapause (Häfker et al. 2018), it is possible to speculate on a potential role of the gene in the transition to diapause and/or the cessation of clock rhythmicity.

None of the investigated genes was exclusively upregulated in late diapause (Fig. 4). High expression levels of ATPsyn and if4E suggest an increase in metabolic activity indicative of the emergence from diapause. Resumption of activity in January and preparation for the ascent to surface waters was further supported by the upregulation of $C y c l B$, which is involved in the cell cycle and tissue development, most likely representing the formation of reproductive tissues that starts in the late phase of diapause (Hirche 1996b, Jónasdóttir 1999). Also, the copepods were preparing for the final molt as indicated by the high expression of ecr, a molting hormone receptor. Hence, the emergence process which ends with the molt to the adult stage and the ascent to the surface is initiated well before the start of the phytoplankton bloom, which in Kongsfjorden happens around April/ May (Leu et al. 2006). Furthermore, these patterns also mimic the data from the low-latitude Loch Etive (Häfker et al. 2018).

\section{Ecological implications}

C. finmarchicus shows a persistent northward shift in its latitudinal distribution range (Reygondeau \& Beaugrand 2011). Similar shifts have also been observed in numerous other marine species, and these distribution shifts have been linked to increasing temperatures as well as changes in food availability (Feng et al. 2016, Chivers et al. 2017). However, for terrestrial species, there is indication that the extreme photoperiods experienced at higher latitudes could limit poleward range expansions, and the same has been proposed for marine organisms (Kaartvedt 2008, Saikkonen et al. 2012). Studies on drosophilid flies from different latitudes show that high-latitude species can maintain circadian rhythmicity under extremely long photoperiods, whereas lower-latitude species become arrhythmic (Menegazzi et al. 2017). The most likely reason for this limitation is that the strong seasonal changes in photoperiod could exceed the range to which the circadian clocks of species from lower latitudes can adapt (Menegazzi et al. 2017). Latitudinal range limitation would force species to live under suboptimal environmental conditions, reducing overall fitness. Alternatively, if species shift to latitudes with light regimes beyond the adaptive range of their circadian clock, this could cause an impairment of diel cycles in physiology and behavior, also resulting in a loss of fitness. In consequence, species can show reduced growth or population size. This would be particularly severe in ecological key species like C. finmarchicus that are a food source for a variety of higher trophic levels. However, our data indicate that C. finmarchicus' circadian clock is robust under the extremely long photoperiods during the active phase at the end of midnight sun. As the copepods in diapause do not show any signs of diel rhythmicity, the lack of light during the polar night probably has little effect on C. finmarchicus fitness (Hirche 1996a, Häfker et al. 2018).

Circadian clocks are not only central in regulating diel rhythmicity but also important for the control and timing of seasonal life cycles because of their ability to measure photoperiod (Goto 2013). In polar habitats, seasonal timing can be crucial, as low light levels and sea ice cover can limit the time of phytoplankton primary production to a very short period (Niehoff et al. 2002, Leu et al. 2006, Søreide et al. 2010). The influences of copepod lipid content and food availability on the timing of diapause in $C$. finmarchicus have been addressed most frequently (e.g. Hind et al. 2000, Maps et al. 2014, Baumgartner \& Tarrant 2017). In contrast, the potential effects of photoperiod on diapause have received relatively little attention (Miller et al. 1991). Nevertheless, there are several reports of photoperiod controlling copepod diapause timing (Marcus \& Scheef 2010). The timing of diapause initiation in C. finmarchicus as well as the number of generations per year vary strongly between populations and latitudes (Kwasniewski et al. 2003, Melle et al. 2014). In Drosophila, clock gene alleles were identified that differ between populations and cause flies to initiate diapause under 
different photoperiods (Sandrelli et al. 2007). A similar genetic diversity in clock gene alleles in C. finmarchicus could explain the differences in diapause timing between populations. The timing of emergence is of particular importance as the species relies heavily on the phytoplankton bloom to fuel reproduction and development of the new generation (Niehoff et al. 2002). Emergence starts well before phytoplankton is available and is usually well synchronized within a population (Marshall \& Orr 1955, Hirche 1996a,b, Ingvarsdóttir et al. 1999, Baumgartner \& Tarrant 2017). This led to the hypothesis that emergence timing is based on photoperiod measurement (Miller et al. 1991). Alternatively, emergence by hourglass timers based on decreasing lipid content or slow continuous development have been proposed (Hind et al. 2000, Saumweber \& Durbin 2006), but these models struggle to explain synchronized emergence in habitats where $C$. finmarchicus produces several generations per year that all initiate diapause at different times. The lack of clock gene cycling in late diapause during the polar night as well as the low light levels make clock-based photoperiod measurement and emergence at this time highly unlikely. The synchronized emergence could, however, be based on a circannual clock that had been entrained by the circadian clock and photoperiod during the active phase in surface waters (tom Dieck 1991, Goldman et al. 2004). Circannual life cycle timing has been described in C. finmarchicus' high Arctic congener C. hyperboreus and other calanoid copepods (Conover 1965, Fulton 1973). Such long-range timing mechanisms can run with impressive precision and could explain the synchronized emergence of copepods at depth without any known seasonal cue (Goldman et al. 2004). In general, if diapause timing in $C$. finmarchicus involves endogenous clocks and possibly habitat-specific clock gene alleles, this could hinder adaptation to the seasonal environmental cycle of newly occupied polar habitats. Furthermore, it would increase the vulnerability to changing environmental conditions as exemplified in a study by Søreide et al. (2010). The authors investigated the influence of the timing of sea ice breakup and phytoplankton bloom on the population dynamics of $C$. finmarchicus and its polar congener $C$. glacialis in an Arctic fjord. They found that while a sea ice breakup 2 mo earlier than usual caused a similar shift in the phytoplankton bloom, the timing of copepod emergence and reproduction stayed the same, once again suggesting an endogenous timer independent of acute external stimuli. This caused a mismatch, as food levels were already decreasing as the newly hatched copepods developed. As a consequence, the biomass of both $C$. finmarchicus and $C$. glacialis was much lower than in the previous year, also affecting higher trophic levels (Søreide et al. 2010). Thus, while endogenous clocks can help to maximize fitness under stable, predictable conditions, they may become detrimental in polar habitats that can show strong interannual variability in environmental parameters (Kahru et al. 2011).

\section{Summary}

Calanus finmarchicus in the high Arctic Kongsfjorden maintained diel clock gene cycling under extremely long photoperiods at the end of midnight sun, but clock rhythmicity was reduced in early diapause and absent in late diapause. Gene expression differences between life phases reflect clock rhythmicity as well as metabolic activity and feeding during the active phase and the emergence process in late diapause. The cessation of clock rhythmicity in diapause was most likely due to physiological changes rather than a lack of light. Hence, the circadian clock of $C$. finmarchicus seems to be able to cope with the extreme polar photoperiods. However, in the variable polar environment, seasonal life cycle timing based on rigid clock mechanisms and photoperiod measurement may cause mismatch situations that could lead to reduced fitness and stock size. Thus, while polar marine species such as C. glacialis and C. hyperboreus may be pushed further poleward by changing environmental conditions, boreal species like $C$. finmarchicus could struggle to take their place because of the inability to adjust their clockbased seasonal timing (Kaartvedt 2008, Saikkonen et al. 2012).

The presence of robust clock gene cycling at the end of midnight sun and the cessation of clock rhythmicity with the physiological switch to diapause suggest that $C$. finmarchicus is well equipped to cope with the extreme polar photoperiods in terms of diel rhythmicity. However, to make a similar statement for the copepod's seasonal rhythmicity, the mechanisms controlling diapause timing are still too poorly understood. A better understanding of marine clock systems in boreal key species such as C. finmarchicus and related high Arctic species such as C. glacialis and C. hyperboreus will be essential to determine how clocks affect seasonal timing, how they function under extreme photoperiods, and how they will respond to changing environmental conditions. 
Acknowledgements. Our work is part of and funded by the Helmholtz Virtual Institute PolarTime (VH-VI-500: Biological timing in a changing marine environment - clocks and rhythms in polar pelagic organisms). It contributes to the PACES (Polar Regions and Coasts in a Changing Earth System) program (Topic 1, WP 4) of the Alfred Wegener Institute Helmholtz Centre for Polar and Marine Research. B.M. received FRAM Centre incentive funding for participation in an Akvaplan-niva chronobiological workshop coordinated by Eva Leu. Work in August 2016 was conducted in cooperation with the French-German research base AWIPEV in Ny-Ålesund and was entered into the Research in Svalbard database (Project-No.: KOP163, RiS-ID: 10494, principal investigator: N.S.H.). We are grateful to members of the Marine Night project led by Jørgen Berge (UiT) and the crew of the R/V 'Helmer Hanssen' as well as to the crew of the R/V 'Teisten' for their support during sampling campaigns. We also thank Malin Daase (UiT) for providing Kongsfjorden phytoplankton data and Jonathan Cohen (UDel), Inka Bartsch (AWI) and Kim Last (SAMS) for their support with the calculation of light attenuation. We are further grateful to the staff of AWIPEV and the Kings Bay Marine Laboratory in Ny-Ålesund for their assistance. Analyses at AWI were supported by Alexandra Schoenle, Kerstin Oetjen and Christiane Lorenzen. David W. Pond (SAMS) generously performed the analyses of copepod lipid content.

\section{LITERATURE CITED}

Aschoff J (1954) Zeitgeber der tierischen Tagesperiodik. Naturwissenschaften 41:49-56

Kåmstedt U (1988) Interspecific, seasonal and diel variations in zooplankton trypsin and amylase activities in Kosterfjorden, western Sweden. Mar Ecol Prog Ser 44:15-24

Båtnes AS, Miljeteig C, Berge J, Greenacre M, Johnsen G (2015) Quantifying the light sensitivity of Calanus spp. during the polar night: potential for orchestrated migrations conducted by ambient light from the sun, moon, or aurora borealis? Polar Biol 38:51-65

Baumgartner MF, Tarrant AM (2017) The physiology and ecology of diapause in marine copepods. Annu Rev Mar Sci 9:387-411

Beale AD, Whitmore D, Moran D (2016) Life in a dark biosphere: a review of circadian physiology in 'arrhythmic' environments. J Comp Physiol B 186:947-968

Chivers WJ, Walne AW, Hays GC (2017) Mismatch between marine plankton range movements and the velocity of climate change. Nat Commun 8:14434

Christie AE, Fontanilla TM, Nesbit KT, Lenz PH (2013) Prediction of the protein components of a putative Calanus finmarchicus (Crustacea, Copepoda) circadian signaling system using a de novo assembled transcriptome. Comp Biochem Physiol Part D Genomics Proteomics 8:165-193

Clark KAJ, Brierley AS, Pond DW, Smith VJ (2013) Changes in seasonal expression patterns of ecdysone receptor, retinoid $\mathrm{X}$ receptor and an A-type allatostatin in the copepod, Calanus finmarchicus, in a sea loch environment: an investigation of possible mediators of diapause. Gen Comp Endocrinol 189:66-73

Conover RJ (1965) Notes on the molting cycle, development of sexual characters and sex ratio in Calanus hyperboreus. Crustaceana 8:308-320

Cottier F, Tverberg V, Inall M, Svendsen H, Nilsen F, Griffiths
C (2005) Water mass modification in an Arctic fjord through cross-shelf exchange: the seasonal hydrography of Kongsfjorden, Svalbard. J Geophys Res Oceans 110:C12005

Cottier FR, Tarling GA, Wold A, Falk-Petersen S (2006) Unsynchronized and synchronized vertical migration of zooplankton in a high arctic fjord. Limnol Oceanogr 51: 2586-2599

* Dale T, Kaartvedt S (2000) Diel patterns in stage-specific vertical migration of Calanus finmarchicus in habitats with midnight sun. ICES J Mar Sci 57:1800-1818

* Dunlap JC, Loros JJ (2016) Yes, circadian rhythms actually do affect almost everything. Cell Res 26:759-760

*Falk-Petersen S, Mayzaud P, Kattner G, Sargent JR (2009) Lipids and life strategy of Arctic Calanus. Mar Biol Res 5: $18-39$

*Feng Z, Ji R, Campbell RG, Ashjian CJ, Zhang J (2016) Early ice retreat and ocean warming may induce copepod biogeographic boundary shifts in the Arctic Ocean. J Geophys Res Oceans 121:6137-6158

Folch J, Lees M, Stanley GHS (1957) A simple method for the isolation and purification of total lipides from animal tissues. J Biol Chem 226:497-509

* Fortier M, Fortier L, Hattori H, Saito H, Legendre L (2001) Visual predators and the diel vertical migration of copepods under Arctic sea ice during the midnight sun. J Plankton Res 23:1263-1278

* Freese D, Søreide JE, Graeve M, Niehoff B (2017) A yearround study on metabolic enzymes and body composition of the Arctic copepod Calanus glacialis: implications for the timing and intensity of diapause. Mar Biol 164:3

F Fu W, Xie W, Zhang Z, Wang S and others (2013) Exploring valid reference genes for quantitative real-time PCR analysis in Plutella xylostella (Lepidoptera: Plutellidae). Int J Biol Sci 9:792-802

F Fulton J (1973) Some aspects of the life history of Calanus plumchrus in the Strait of Georgia. J Fish Res Board Can 30:811-815

*Gabrielsen TM, Merkel B, Søreide JE, Johansson-Karlsson E and others (2012) Potential misidentifications of two climate indicator species of the marine arctic ecosystem: Calanus glacialis and C. finmarchicus. Polar Biol 35: 1621-1628

Goldman B, Gwinner E, Karsch FJ, Saunders D, Zucker I, Gall GF (2004) Circannual rhythms and photoperiodism. In: Dunlap JC, Loros JJ, DeCoursey PJ (eds) Chronobiology: biological timekeeping. Sinauer, Sunderland, MA, p 107-142

Goto SG (2013) Roles of circadian clock genes in insect photoperiodism. Entomol Sci 16:1-16

光Häfker NS, Meyer B, Last KS, Pond DW, Hüppe L, Teschke M (2017) Circadian clock involvement in zooplankton diel vertical migration. Curr Biol 27:2194-2201.e3

光Häfker NS, Teschke S, Last KS, Pond DW, Hüppe L, Meyer B (2018) Calanus finmarchicus seasonal cycle and diapause in relation to gene expression, physiology, and endogenous clocks. Limnol Oceanogr, doi:10.1002/lno. 11011

*Hansen BH, Altin D, Hessen KM, Dahl U, Breitholtz M, Nordtug T, Olsen AJ (2008) Expression of ecdysteroids and cytochrome P450 enzymes during lipid turnover and reproduction in Calanus finmarchicus (Crustacea: Copepoda). Gen Comp Endocrinol 158:115-121

*Helaouët P, Beaugrand G (2007) Macroecology of Calanus finmarchicus and C. helgolandicus in the North Atlantic 
Ocean and adjacent seas. Mar Ecol Prog Ser 345: 147-165

Hind A, Gurney WSC, Heath M, Bryant AD (2000) Overwintering strategies in Calanus finmarchicus. Mar Ecol Prog Ser 193:95-107

Hirche HJ (1996a) Diapause in the marine copepod, Calanus finmarchicus - a review. Ophelia 44:129-143

Hirche HJ (1996b) The reproductive biology of the marine copepod, Calanus finmarchicus - a review. Ophelia 44: 111-128

Ingvarsdóttir A, Houlihan DF, Heath MR, Hay SJ (1999) Seasonal changes in respiration rates of copepodite stage $\mathrm{V}$ Calanus finmarchicus (Gunnerus). Fish Oceanogr 8:73-83

Jónasdóttir SH (1999) Lipid content of Calanus finmarchicus during overwintering in the Faroe-Shetland Channel. Fish Oceanogr 8:61-72

Kaartvedt S (2008) Photoperiod may constrain the effect of global warming in arctic marine systems. J Plankton Res 30:1203-1206

Kahru M, Brotas V, Manzano-Sarabia M, Mitchell BG (2011) Are phytoplankton blooms occurring earlier in the Arctic? Glob Change Biol 17:1733-1739

Kobelkova A, Goto SG, Peyton JT, Ikeno T, Lee RE, Denlinger DL (2015) Continuous activity and no cycling of clock genes in the Antarctic midge during the polar summer. J Insect Physiol 81:90-96

Kwasniewski S, Hop H, Falk-Petersen S, Pedersen G (2003) Distribution of Calanus species in Kongsfjorden, a glacial fjord in Svalbard. J Plankton Res 25:1-20

Last KS, Hobbs L, Berge J, Brierley AS, Cottier F (2016) Moonlight drives ocean-scale mass vertical migration of zooplankton during the Arctic winter. Curr Biol 26: 244-251

Kenz PH, Roncalli V, Hassett RP, Wu LS, Cieslak MC, Hartline DK, Christie AE (2014) De novo assembly of a transcriptome for Calanus finmarchicus (Crustacea, Copepoda) - the dominant zooplankter of the North Atlantic Ocean. PLOS ONE 9:e88589

Keu E, Falk-Petersen S, Kwaśniewski S, Wulff A, Edvardsen K, Hessen DO (2006) Fatty acid dynamics during the spring bloom in a high Arctic fjord: importance of abiotic factors versus community changes. Can J Fish Aquat Sci 63:2760-2779

Livak KJ, Schmittgen TD (2001) Analysis of relative gene expression data using real-time quantitative PCR and the $2^{-\Delta \Delta C T}$ method. Methods 25:402-408

Lutz VA, Sathyendranath S, Head EJH (1996) Absorption coefficient of phytoplankton: regional variations in the North Atlantic. Mar Ecol Prog Ser 135:197-213

Mackey SR (2007) Biological Rhythms Workshop IA: molecular basis of rhythms generation. Cold Spring Harb Symp Quant Biol 72:7-19

Maps F, Record NR, Pershing AJ (2014) A metabolic approach to dormancy in pelagic copepods helps explaining inter- and intra-specific variability in life-history strategies. J Plankton Res 36:18-30

Marcus NH, Scheef LP (2010) Photoperiodism in copepods. In: Nelson RJ, Denlinger DL, Somers DE (eds) Photoperiodism: the biological calendar. Oxford University Press, New York, NY, p 193-217

Marshall SM, Orr AP (1955) The biology of a marine copepod, Calanus finmarchicus (Gunnerus). Oliver and Boyd, London

Meireles-Filho ACA, Kyriacou CP (2013) Circadian rhythms in insect disease vectors. Mem Inst Oswaldo Cruz 108: $48-58$

Melle W, Runge J, Head E, Plourde S and others (2014) The North Atlantic Ocean as habitat for Calanus finmarchicus: environmental factors and life history traits. Prog Oceanogr 129:244-284

*Menegazzi P, Dalla Benetta E, Beauchamp M, Schlichting M, Steffan-Dewenter I, Helfrich-Förster C (2017) Adaptation of circadian neuronal network to photoperiod in high-latitude European drosophilids. Curr Biol 27: 833-839

Miller CB, Cowles TJ, Wiebe PH, Copley NJ, Grigg H (1991) Phenology in Calanus finmarchicus; hypotheses about control mechanisms. Mar Ecol Prog Ser 72:79-91

Niehoff B, Madsen S, Hansen B, Nielsen T (2002) Reproductive cycles of three dominant Calanus species in Disko Bay, West Greenland. Mar Biol 140:567-576

Nielsen TG, Kjellerup S, Smolina I, Hoarau G, Lindeque P (2014) Live discrimination of Calanus glacialis and C. finmarchicus females: Can we trust phenological differences? Mar Biol 161:1299-1306

*Panda S, Antoch MP, Miller BH, Su AI and others (2002) Coordinated transcription of key pathways in the mouse by the circadian clock. Cell 109:307-320

* Poelchau MF, Reynolds JA, Elsik CG, Denlinger DL, Armbruster PA (2013) Deep sequencing reveals complex mechanisms of diapause preparation in the invasive mosquito, Aedes albopictus. Proc R Soc B 280:20130143

*PProkopchuk I, Sentyabov E (2006) Diets of herring, mackerel, and blue whiting in the Norwegian Sea in relation to Calanus finmarchicus distribution and temperature conditions. ICES J Mar Sci 63:117-127

R Development Core Team (2013) R: a language and environment for statistical computing. R Foundation for Statistical Computing, Vienna. www.R-project.org

* Reygondeau G, Beaugrand G (2011) Future climate-driven shifts in distribution of Calanus finmarchicus. Glob Change Biol 17:756-766

* Runge JA (1988) Should we expect a relationship between primary production and fisheries? The role of copepod dynamics as a filter of trophic variability. Hydrobiologia 167-168:61-71

Saikkonen K, Taulavuori K, Hyvönen T, Gundel PE and others (2012) Climate change-driven species' range shifts filtered by photoperiodism. Nat Clim Chang 2:239-242

Salminen TS, Vesala L, Laiho A, Merisalo M, Hoikkala A, Kankare M (2015) Seasonal gene expression kinetics between diapause phases in Drosophila virilis group species and overwintering differences between diapausing and non-diapausing females. Sci Rep 5:11197

* Sandrelli F, Tauber E, Pegoraro M, Mazzotta G and others (2007) A molecular basis for natural selection at the timeless locus in Drosophila melanogaster. Science 316: 1898-1900

Saumweber WJ, Durbin EG (2006) Estimating potential diapause duration in Calanus finmarchicus. Deep Sea Res II 53:2597-2617

Schanz F (1985) Vertical light attenuation and phytoplankton development in Lake Zürich. Limnol Oceanogr 30: 299-310

Søreide JE, Leu E, Berge J, Graeve M, Falk-Petersen S (2010) Timing of blooms, algal food quality and Calanus glacialis reproduction and growth in a changing Arctic. Glob Change Biol 16:3154-3163 
Strauss J, Dircksen H (2010) Circadian clocks in crustaceans: identified neuronal and cellular systems. Front Biosci 15:1040-1074

Tarrant AM, Baumgartner MF, Verslycke T, Johnson CL (2008) Differential gene expression in diapausing and active Calanus finmarchicus (Copepoda). Mar Ecol Prog Ser 355:193-207

Teschke M, Wendt S, Kawaguchi S, Kramer A, Meyer B (2011) A circadian clock in Antarctic krill: an endogenous timing system governs metabolic output rhythms

Editorial responsibility: Sigrun Jónasdóttir, Charlottenlund, Denmark in the euphausid species Euphausia superba. PLOS ONE 6:e26090

* Tessmar-Raible K, Raible F, Arboleda E (2011) Another place, another timer: marine species and the rhythms of life. BioEssays 33:165-172

* Thaben PF, Westermark PO (2014) Detecting rhythms in time series with RAIN. J Biol Rhythms 29:391-400

* tom Dieck I (1991) Circannual growth rhythm and photoperiodic sorus induction in the kelp Laminaria setchellii (Phaeophyta). J Phycol 27:341-350

Submitted: January 18, 2018; Accepted: July 13, 2018

Proofs received from author(s): August 20, 2018 